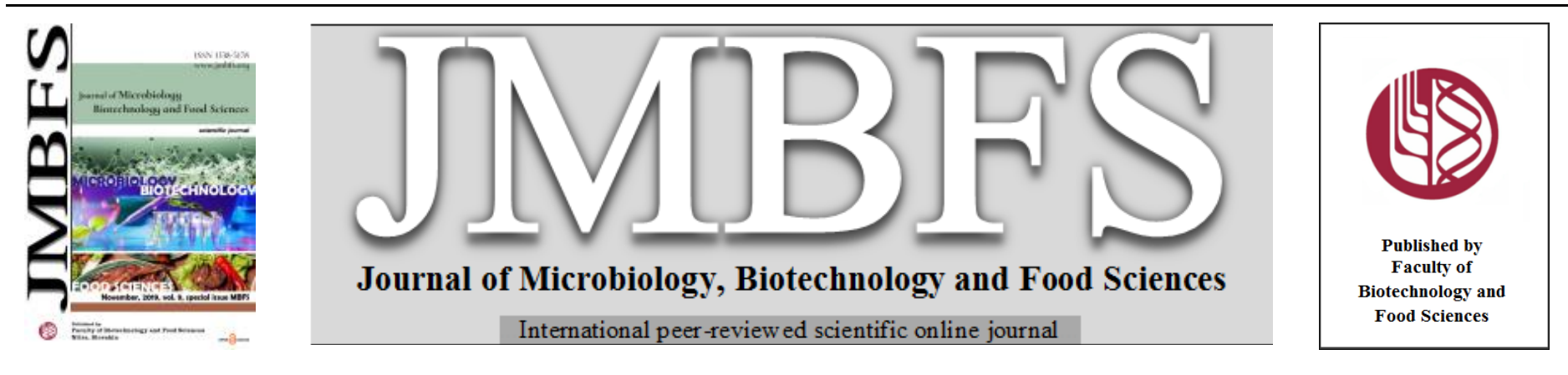

\title{
PRACTICE AND QUESTIONS OF FOOD ALLERGENS LABELLING AND RECOMMENDED DISCLOSURE OVER THE BACKGROUND OF THEIR CROSS-REACTIONS
}

\author{
Jana Žiarovská*1, Lucia Zeleňáková ${ }^{2}$ Lucia Zamieškovál, Jana Bilčíková ${ }^{3}$, Dominika Herzegová ${ }^{2}$
}

\section{Address(es):}

${ }^{1}$ Slovak University of Agriculture, Faculty of Agrobiology and Food Resources, Department of Genetics and Plant Breeding, Tr. A. Hlinku 2, 94976 Nitra.

${ }^{2}$ Slovak University of Agriculture, Faculty of Biotechnology and Food Sciences, Department of Food Hygiene and Safety, Tr. A. Hlinku 2, 94976 Nitra.

${ }^{3}$ Slovak University of Agriculture, Research Centre AgroBioTech, Tr. A. Hlinku 2, 94976 Nitra.

*Corresponding author: jana.ziarovska@uniag.sk

doi: 10.15414/jmbfs.2019.9.special.473-477

\section{ARTICLE INFO}

Received 18. 7. 2019

Revised 30. 9. 2019

Accepted 7. 10. 2019

Published 8. 11. 2019

$\overline{\text { Review }}$

\begin{abstract}
Allergies are currently one of the most common chronic diseases which affect millions of people worldwide. The presence of allergens in food products have to be labelled, however, only in case of several classes of allergen source. Actual knowledge points out to the fact, that patients are sensitized by many allergens and often suffer from various cross-allergies. This stresses the existing disproportionality between known data and practice. The study therefore aims to analyze the current state of accessibility to information and disunity in labeling and also in response of practice to scientific findings. Further, based on the examples of apples and peaches, the cross-reactivity of food allergens is discussed for the base of the possible wider labelling in the way that practice will reflect the scientific knowledge more actual.
\end{abstract}

Keywords: food allergy, cross-reactivity, allergen labeling, list of allergens

\section{INTRODUCTION}

Allergy is currently the leading chronic disease in Europe affecting more than $20 \%$ of population. In the close future its prevalence is even predicted to increase of $40 \%$. Around 17 million of European population suffer from food allergies and 3.5 million among patients are under the age of 25 . The geographic variability of major allergens is reported to reflect a potential interaction of genetic factors, age, cultural and dietary habits together with the time of first exposure to allergenic products (Dalal et al., 2002) and other factors such as socioeconomic class (Gupta et al., 2011), urbanization - so called hygiene hypothesis (Gupta et al., 2012), ethnicity (Greenhawt et al., 2013) and migration patterns (Koplin et al., 2014). Current medicine does not provide any proactive treatment of food allergy to patients with classical IgE-mediated allergy and they are often prescribed only with symptom controlling drugs. The only way to restrain allergic reactions is to avoid the foods containing dangerous allergen substances (Eigenmann, 2001).

The practical implementation of the approach means limitations and adaptations of the diet and lifestyle which is manifested in cautious and prudent purchase and consumption of foodstuffs. Patients with food allergy are limited in public catering since they are not given sufficient information about the meal. The realization of such restrictions is aggravated by the fact that the legislation in many countries does not require products to be labelled with their composition and all allergenic substances. This leads to situations where consumers randomly pick precarious food products which results in allergic reaction with potentially fatal consequences (Burks et al., 2001; Schäppi et al., 2001). Labeling is an issue of relevance to food allergic patients of fresh, processed and pre-packed foods, as accidental ingestion of food allergens due to labelling amboguities is a modifiable risk factor (Fiocchi et al., 2016).

In the view of the raise in food variety and the increased prevalence of food allergy, avoiding specific foods and allergen ingredients represent a serious interference in comfort and personal life (Fiocchi et al., 2011; Nwaru et al., 2014). Formation and regulation of conditions for effective labeling of food allergens is an essential issue not only for patients themselves but also for their families - in Europe it counts about 17 million people. The disproportionality of knowledge and practice is still creating the indisputable need to make the issue a priority task (Figure 1). This study therefore aims to analyze the actual knowledge of cross-reactive food allergens and to emphasize the inconsistency of labeling and also in reaction of practice to scientific findings on the examples of apple allergen Mal d 1 and peach allergen Pru p 3.

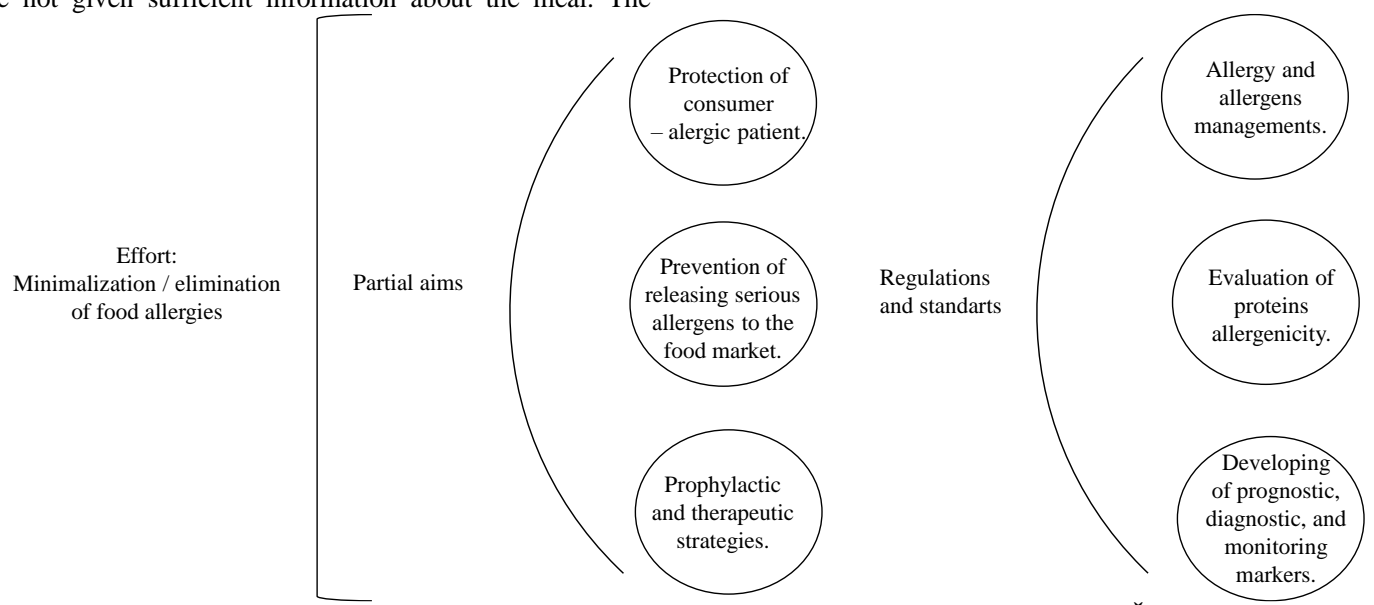

Figure 1 Integrated approach to food allergies in research aimed at practical application of acquired knowledge (Žiarovská, Zeleňáková, 2017) 


\section{ACTUAL PRACTICE IN FOOD ALLERGENS LABELING AND RECOMMENDED DISCLOSURE}

With the growth of world food production, development of new technological processes as well as more efficient transport systems we have to deal in particular with effective labeling of allergen substances. Allergen labeling laws regulate the way allergens are included on a prepackaged food's label. Besides the EU, allergens are obligatorily marked on food products in Argentina, Australia Brazil, Canada, China and Hong Kong, Japan, Kuwait, Malaysia, Mexico, New Zealand, Singapore, South Africa, South Korea and the USA (Gendel, 2012; Revák and Golian, 2012; Allen et al., 2014). In the EU the legislative demands labeling of 14 groups, 8 of which are of plant origin (European Commission: Food labeling - EU rules)

- Group 1 - cereals containing gluten (i.e., wheat, rye, barley, oats, kamut or their hybrid varieties) and products thereof

- Group 5 - peanuts and products thereof

- Group 6 - soya beans and products thereof

- Group 8 - nuts (such as almonds, hazelnuts, walnuts, cashew nuts, pecans nuts, peanuts, pistachios, macadam nuts and Queensland nuts and products thereof except for nuts which are used for the production of spirits

- Group 9 - celery and products thereof

- Group 10 - mustard and products thereof

- Group 11 - sesame seeds and products thereof

- Group 13 - lupin and products thereof

When comparing Europe mandatory labeling to other countries, following differencies exist. Tatrazin is required to be labeled in Argentina and Brazil. In Japan, standartly are labeled eggs, milk, wheat, buckwheat, peanuts, shrimps and crabs. Recommended disclosure is for apple, peach, yam, banana, orange, kiwifruit, walnut, abalone, squid, salmon roe, beef, salmon, mackerel, chicken, pork, soybean, Matsuke mushroom and gelatin and a species specification is required for crustaceae. In South Korea, labeling of eggs, milk, wheat, buckwheat, peanuts, soybeans, wheat, mackerel, prawn/shrimp, crab, pork, peaches and tomatoes.

Nevertheless, there is a still growing requirement to mark other allergen plant sources, since the list of allergens with prominent evidence of clinical allergy cases is much wider that the required 8 groups of plant food allergens (Table 1)

Table 1 Food allergens with reported clinical cases apple, apricot, banana, blackberry (clinical symptoms described only for pollen), cherry, cranberry, date, fig,

Fruits grape, Chinese date, kiwi, lemon, lime, lychee, mango, sugar melon, olive, orange, papaya, peach, pear, hurmi kaki, pineapple, plum, raspberry, currant, strawberry, melon

Cereals and pseudocereals $\quad \begin{gathered}\text { barley, buckwheat, corn, amaranth, oat, } \\ \text { rice, rye, wheat }\end{gathered}$

Legume chick pea, senna, beans (white, red),
lupin, lentils, peas, soybeans peanuts, almonds, cashew nuts, coconuts, hazelnuts, linseed, lupine, macadam nuts, pecan nuts, pine nuts,

Nuts and seeds pistachios, poppy seeds, pumpkin seeds, rapeseed, sesame, sugar beet, edible chestnuts, walnuts

anise, basil, laurel, black pepper, caraway seeds, cinnamon, clove,

Spices coriander, curry, dill, fennel, ginger, marjoram, oregano, mint, mustard, nutmeg, parsley, saffron, thyme asparagus, eggplant, avocado, cabbage, carrot, cauliflower, celery, cucumber, fennel, garlic, lettuce, onion, pepper, potato, spinach, pumpkin, tomato

Vegetables green coffee, cocoa, honey, Others Saccharomyces cerevisiae
0-6 years and $6.6 \%$ of adults are allergic to apples (Kiewning and SchmitzEiberger, 2014). Food allergies are often cases of secondary allergy caused by a cross-reaction between pollen allergens and their homologs. Here, a patient is sensitised by an aeroallergen from pollen which is later followed by immune response to structurally similar allergens present in different foods (Worm et al., 2015). Symptoms and the allergic reaction are usually manifested as oral allergic syndrome (OAS) (Worm et al., 2015).

An example of secondary food allergy is a group of Bet $\mathrm{v} 1$ protein, the main birch pollen allergen and its homologs. Bet v 1 homologs can be found in a wide range of fruits and vegetables with varying degrees of clinical significance (Table 2). Around $75 \%$ people with birch pollen allergy have OAS after eating food containing its cross-allergens.

$\underline{\text { Table } 2 \text { Fruits and vegetables with cross-reactivity to birch pollen }}$

\begin{tabular}{lc}
\hline Actinidiaceae & kiwi fruit \\
\hline Betulaceae & hazelnut \\
\hline Anacardiaceae & mango \\
\hline Apiaceae vegetables & carrots, celery \\
\hline Cucurbitaceae & $\begin{array}{c}\text { melon, watermelon, cataloupe, } \\
\text { zicchini, cucumber }\end{array}$ \\
\hline Fabaceae & peanut, chickpea \\
\hline Musaceae & banana \\
Rosaceae & $\begin{array}{c}\text { almond, apple, apricot, cherry, } \\
\text { peach, pear, plum }\end{array}$ \\
\hline Solanaceae & tomato, potato \\
\hline Miscellaneous fruits and vegetables & $\begin{array}{c}\text { chilli peppers, corn, strawberries, } \\
\text { soybeans, lettuce }\end{array}$ \\
\hline
\end{tabular}

One of the clinically most significant homolog relevant for the area of central Europe is Mal d 1 belonging to the PR-10 protein family (PR - pathogenesis related). Mal d 1 itself is not capable of sensitization due to its lability under higher temperatures and enzymatic digestion, however, it induces allergic reaction after Bet v 1 sensitization (URL 1). Prevalence of allergy to apples in the group of tree pollen allergic patients was reported as ranged from $13 \%$ (Yamamoto et al., 1995) up to the $90 \%$ (Dreborg and Foucard 1983).

Since Mal d 1 protein is not stable, it loses its allergenic potential after technological food processing under high temperatures and therefore, likewise processed food is safe for individuals allergic to the protein. On the other hand, cold-pressed juice (not just apple flavor), freeze-dried fruit and vegetable mix or products containing apple vinegar are dangerous for a hypersensitive individual. Moreover, from the current findings it is evident, that the allergenicity of an apple is strongly dependent on apple variety. Based on clinical observations to patients reaction apple varieties are divided into high, medium and low allergenic potential groups (Kiewning and Schmitz-Eiberger, 2014). Varieties such as Elise and Santana are less allergenic and so are more suitable for comsumption for allergic patients compared to Renate, Cortland or Golden Delicious (Kootstra et al., 2007; Vlieg-Boerstra et al., 2011; Vlieg-Boerstra et al., 2013; Wagner et al., 2016)

Mal d 1, as a member of pathogenesis-related proteins, has been found to be induced by various stress factors (Botton et al., 2009). For that reason the allergenicity of an apple strongly depends also on growing and storage conditions (Kiewing et al., 2014). Patients with testified allergy to apples (by skin prick test, SPT) are in general recommended to avoid consuming apples. However, they lack the information whether they can not eat apples only in fresh form (the case of allergy to unstable protein Mal d 1) or also should avoid heat-processed apples (in case of allergy to thermostable Mal d 2 apple allergen) (Smole et al., 2008).

The disproportionality between compulsory labelled allergens and their crossreactive substances is in practice handled at the level of patients' awareness of the fact. However, the only existing treatment - avoiding consumption of foodstuf containg the allergen, is complicated by several aspects, particularly in the case of panallergens:

- obligatory labeling of food allergens involves only a small fraction of them

- data on cross-allergens are not centralized, therefore patients are usually informed only from a flyer or a brochure (Figure 2);

- counterfeited foodstuffs import allergens which are for patients impossible to trace;

- information on cross-allergens from new foods meets patients with a considerable delay.

\section{EXAMPLES OF RELEVANT CROSS-REACTORS WITHOUT LABELING IF FOODSTUFS}

Cross-reactivity in allergic reactions occurs when the proteins in one substance are similar to the proteins in another. In case of numerous allergens, consumers are exhibited to health-threatening situations even despite easily manageable accessibility of information to increase patients' awareness. Nowadays, allergy to apple protein Mal d 1 is rapidly growing among European population, which is associated with wide distribution of birch pollen. About $11.5 \%$ of children aged 


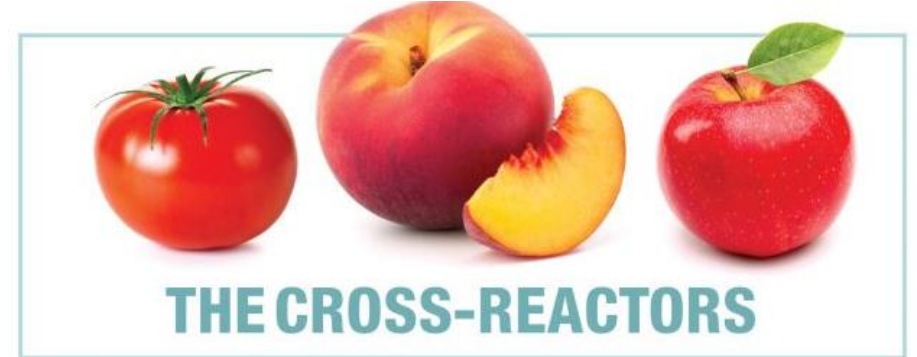

TREE POLLEN (Typically birch and alder)

Fruits: Apple, apricot, cherry, fig (still being studied), kiwi, lychee, nectarine, pear, plum, peach, prune, persimmon, strawberry

Vegetables: Beans, carrot, celery, green pepper, potato, tomato, parsnip, peas Nuts: Almond, hazelnut, walnut

Spices: Anise, basil, dill, caraway, chicory (early evidence only), coriander, cumin, fennel, marjoram, oregano, parsley, paprika, pepper, tarragon, thyme Other foods: Lentils, peanut, soybean, sunflower seeds

Figure 2 Example of an availability of information about cross-reacting foods to Bet $\mathrm{v} 1$ sensitized patients (www.allergicliving.com)

The illustrated biological and immunological relation in the example of apple allergen Mal d 1 emphasize the need to reassess the extent and details of patients' awareness.

Another example of clinically relevant cross-reacted food is peach and its thermostable allergen - the lipid transfer protein Prup 3. Pru p 3 is an allergen that is the cause of the cross- reaction in the case of patients with mugwort pollen allergy (Lombardero et al., 2004, Gao et al., 2013). Moreover, the thermostability of Pru 3 causes allergic reactions during the year regardless the peaches harvesting season. In the area of Europen union, fresh peaches are available from April to October, while mugwort pollen is in the air from late June to October. However, hypersensitivity in the wormwood-peach reaction is conditioned in the direction of primary sensitization. For patients with primary allergy to peaches, the reaction to the mugwort pollen allergen is often without of clinical symptoms. For patients with primary wormwood allergy, however, the allergic response to peach allergens is highly probable (Pastorello et al., 2002; Lombardero et al., 2004, Egger et al., 2006; Sanchez-Monge et al., 2006; Wangorsch et al. al., 2014). For years, the condition of the development of allergic symptoms has been reported mainly in areas where the mugwort is main allergenic source, in southern Europe and China (Lombardero et al., 2004; Gao et al., 2013), but probably with an expanding range of this invasive specie, recent sensitization to Pru p 3 has also been reported in the region of Central Europe (Mothes-Luksch et al., 2017). Lipid transfer proteins of mugwort pollen are typical for their cross-reactions with many other LTPs from different plants. In the case of equivalent allergens of apples and peaches, they are identical in fist $30 \mathrm{~N}$-terminals (Diaz-Perales et al., 2000). In the cross-reaction in the mugwort peach, relevant are allergens from the group of lipid transfer proteins Art in 3 and Pru p 3 and the profilins Art v 4 and Pru p 4 (Egger et al., 2006). Cross-reactivity is reported in a group of patients from South Europe where Art 3 is the primary sensitizing allergen, although in the Mediterranean area peach food allergy is caused by primary sensitization of the Pru 3 allergen (Lombardero et al. , 2004). Similarly, cross-reactivity of mugwort and peach is also known in northern China, where patients are also sensitized primarily by wormwood pollen (Gao et al., 2013). The predicted geographic expansion of this cross-reaction is based on the predominance of mugwort pollen in the relevant regions. The most recent study, however, is currently describing Pru 3 as a marker allergen for the sensitization of patients to lipid transfer proteins in the environment of Central Europe (Mothes-Luksch et al., 2017). It is not easy to estimate of prevalence of peach allergy due to differences in study populations, dietary habits or geographical areas (northern or southern Europe) or differences in diagnostic procedures (Bessler aet al., 2000)

Currently reported biological and immunological context of the example of Pru p 3 allergen of peaches point to the need to review the scope and details of mandatory informations about the allergens for the consumer. However, these are united in the EU only for selected groups, and we have found only one web page to find out that, besides the benefits of eating peaches, they also show their allergenicity (Figure 3).

\section{HEALTH BENEFITS OF PEACH organic|}

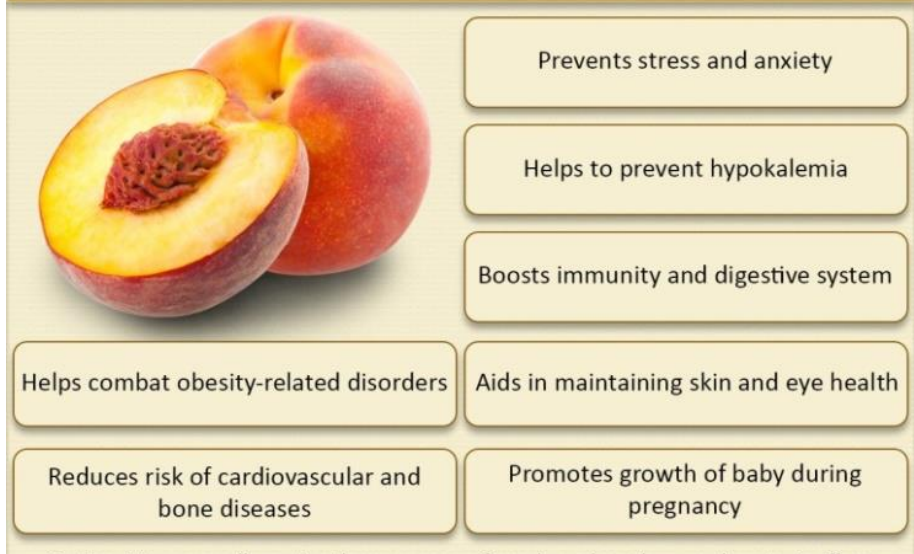

Caution: May cause allergy. Avoid excess usage of peach seeds as they may have toxic effects

$$
\text { www.organicfacts.net }
$$

Figure 3 Information about the allergenic potential of peaches in the web page www.organicfacts.net

\section{INTEGRATION OF THE ALLERGENS MANAGEMENT BY ALLEGOMICS AND IN SILICO GENERATED DATA}

A very new approach in the complex management of the allergies is based not only on the cross-reactions, but on combining the existing knowledge with the allergomic one. The definition of allergen itself is dependent on the point of view, if it is immunological, clinical, proteomic or genomic one. When consider the immunological definition, allergen is an $\operatorname{IgE}$ reactive antigen in an allergenic patient, but its clinical manifestation has many other circumstances and is based on many factors. The evaluation of allergenic sources is connected to the extention of the diversity of allergens where the all proteins of an allergenic source are analysed as a background net for the allergens itselves and personalized in the relationships of major and minor allergens. Another important evaluation approach is extention of the diversity of $\operatorname{IgE}$ response. Here, the $\operatorname{IgE}$ specific characteristics in the reaction against allergenic source is asked if is correlate with clinical and sensitization data. All this provide a complementary methods to describe and characterize allergen diversity as well as antibody response diversity (Poncet et al., 2010).

Another new approach, such as microarray generated data, are a powerful methods, that personalized and find the differences in the specific sensitization profiles of individual allergic patients in the studies (Shahali et al., 2014). Using of microarray for in vitro diagnosis purposes provide results of IgE binding on more than 100 native and recombinant allergens that are relevant group markers of allergenic sources (Mari et al., 2010). A many of different allergen reactivities are explored using this approach and are based on physio-pathological models of well characterized and known molecular allergens. The inability of the microarray strategy is to evaluate reactivity to allergens that has not been previously reported. Here, the generating of DNA, cDNA and RNA data is another useful step that can provide a new molecular markers for the proteomically up to now non-defined allergens based on its basic nucleotide sequence homology (Houben at el., 2019; Žiarovská and Zeleňáková, 2019) Combining the basic proteomic, immunological and genomic methods together in the research, an effective workflow (Figure 4) is currenly available for the rapid screening of allergens in the allergen sources and in the future, it will be applicable as a basic data generated approach in the practical and personalized treatment of allergic patients. 


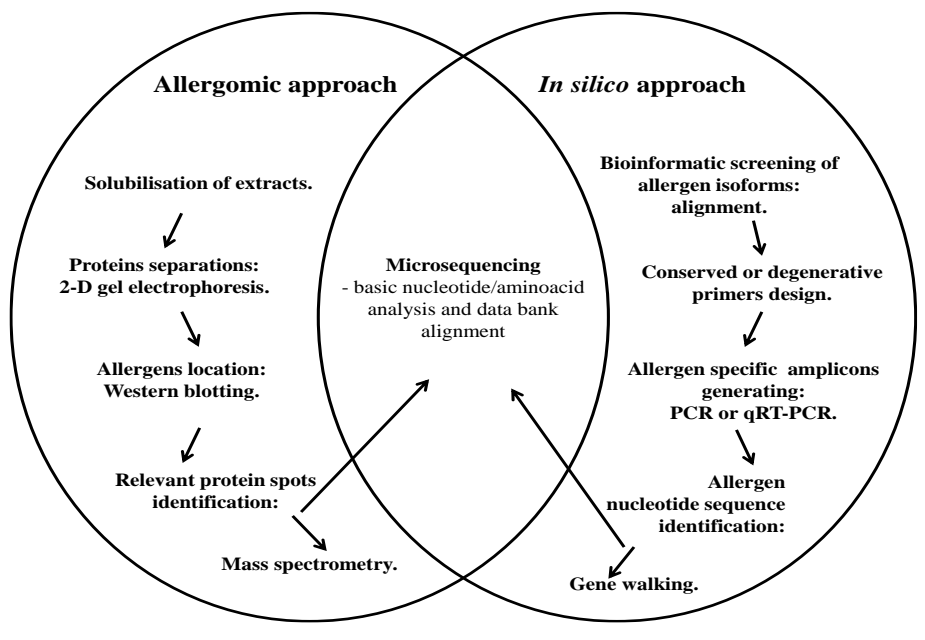

Figure 4 Allergens analysis workflow based on allergomics and in silico generated data

\section{CONCLUSION}

Based on the current findings the class of plant food sources causing allergies is far wider than the group of plant species which are obligatory required to be designated on food products. In several countries different plant allergens are optionally labelled. Sensitization of patients by pollen allergens is, however, influenced by availability of foods during most of the year and wide distribution of pollen. Therefore, reassessment of existing list of allergens needs to react more promptly.

Acknowledgments: This research was supported by project KEGA 007SPU4/2017 Linking theory and practice in the study program Food safety and control by implementing modern didactic technologies within various forms of learning.

\section{REFERENCES}

ALLEN, K. J., TURNER, P.J., PAWANKAR, R., TAYLOR, S., SICHERER, S., LACK, G., ROSARIO, N., EBISAWA, M., WONG, G., MILLS, E.N.C., BEYER, K., FIOCCHI, A., SAMPSON, H.A. 2014. Precautionary labelling of foods for allergen content: are we ready for a global framework? World Allergy Organization Journal, 7, 10. http://dx.doi.org/10.1186/1939-4551-7-10

BESSLER, M., CUESTA HERRANZ, J., FERNÁNDEZ-RIVAS, M. 2000 Allergen Data Collection: Peach (Prunus persica). Internet Symposium on Food Allergens, 2(4), 2000.

BOTTON, A., LEZZER, P., DORIGONI, A., RUPERTI, B., RAMINA, A. 2009 Environmental factors affecting the expression of apple allergen-encoding genes. The Journal of Horticultural Science and Biotechnology, 84, 182-187. https://doi.org/10.1080/14620316.2009.11512618

BURKS, A.W., CHRISTIE, L., ALTHAGE, K.A., KESLER, J.M., ALLGOOD, G.S. 2001. Randomized, double-blind, placebo controlled, food allergy challenge to olestra snacks. Regulatory Toxicology and Pharmacology, 34, 178-181. http://dx.doi.org/10.1006/rtph.2001.1488

DALAL, I., BINSON, I., REIFEN, R., AMITAI, Z., SHOHAT, T., RAHMANI S., LEVINE, A., BALLIN, A., SOMEKH, E. 2002. Food allergy is a matter of geography after all: sesame as a major cause of severe IgE - mediated food allergic reactions among infants and young children in Israel. Allergy, 57(4), 362365.

DREBORG, S., FOUCARD, T. 1983. Allergy to apple, carrot and potato in children with birch pollen allergy. Allergy, 38(3):167-72.

EGGER, M., MUTSCHLECHNER, S., WOPFNER, N., GADERMAIER, G., BRIZA, P., FERREIRA, F. 2006. Pollen-food syndromes associated with weed pollinosis: an update from the molecular point of view. Allergy, 61, 461-476. http://dx.doi.org/10.1111/j.1398-9995.2006.00994.x

EIGENMANN, P.A. 2001. Food allergy: a long way to safe processed foods Allergy 2001; 56: 1112-1113.

EUROPEAN COMMISSION: Food labeling - EU rules. http://ec.europa.eu/food/food/labellingnutrition/foodlabelling/index_en.htm.

FIOCCHI, A., SAMPSON, H. A., BAHNA, S.L., LACK, G. 2011. Food Allergy. In WAO White Book on Allergy. Edited by Pawankar, R., Holgate, S.T. Canonica, G.W., Lee, A.J. et al., 2013. Food allergy in Asia: how does it compare? Asia Pacific Allergy 2013, 3, 3-14.

FIOCCHI, A., DAHDAH, L., RICCARDI, C., MAZZINA, O., FIERRO, V 2016. Precautionary labelling of cross-reactive foods: The case of rapeseed Asthma Research and Practice, 2, 13. http://dx.doi.org/10.1186/s40733-016$\underline{0028-4}$

GAO, Z.S., YANG, Z.W., WU, S.D., WANG, H.Y., LIU, M.L., MAO, W.L., WANG, J., GADERMAIER, G., FERREIRA, F., ZHENG, M., VAN REE, R.
2013. Peach allergy in China: a dominant role for mugwort pollen lipid transfer protein as a primary sensitizer. Journal of Allergy and Clinical Immunology, 131, 224-226. http://dx.doi.org/10.1016/j.jaci.2012.07.015

GENDEL, S.M. 2012. Comparison of international food allergen labeling regulations. Regulatory Toxicology and Pharmacology, 63(2), 279-85. http://dx.doi.org/10.1016/j.yrtph.2012.04.007

GREENHAWT, M., WEISS, C., CONTE, M. L., DOUCET, M., ENGLER, A., CAMARGO, C. A. 2013. Racial and ethnic disparity in food allergy in the United States: a systematic review. The Journal of Allergy and Clinical Immunology: In Practice, 1(4), 378-386.

DIAZ-PERALES, A., LOMBARDERO, M., SANCHEZ-MONGE, R. GARCIA-SELLES, F.J., PERNAS, M., FERNANDEZ-RIVAS, M., BARBER, D., SALCEDO, G. 2000. Lipid-transfer proteins as potential plant panallergens: cross-reactivity among proteins of Artemisia pollen, Castanea nut and Rosaceae fruits, with different IgE-binding capacities. Clinical and Experimental Allergy, 30(10), 1403-1410. http://dx.doi.org/10.1046/j.1365-2222.2000.00909.x

GUPTA, R. S., SPRINGSTON, E. E., SMITH, B., WARRIER, M. R., PONGRACIC, J., HOLL, J. L. 2012. Geographic variability of childhood food allergy in the United States. Clinical pediatrics, 51(9), 856-861. http://dx.doi.org/10.1177/0009922812448526

GUPTA, R. S., SPRINGSTON, E. E., WARRIER, M. R., SMITH, B., KUMAR R., PONGRACIC, J., HOLL, J. L. 2011. The prevalence, severity, and distribution of childhood food allergy in the United States. Pediatrics, 128(1), e9e17. http://dx.doi.org/10.1542/peds.2011-0204

HOUBEN, G., BLOM, M., ALVITO, P., ASSUNCC̃̃O, R., CREVEL, R., KRUSE FÆSTE, CH., LEE, T.M., BERNHARD MADSEN, CH., REMINGTON, B., STROHEKERG, T., VASSILOPOULOU, E., VERHOECKX, K., ŽIAROVSKÁ, J., CONSTABLE, A. 2019. Defining the targets for the assessment of IgE-mediated allergenicity of new or modified food proteins. Food and Chemical Toxicology, 127, 61-69. http://dx.doi.org/10.1016/j.fct.2019.02.036

KIEWNING, D., SCHMITZ-EIBERGER, M. 2014. Effects of long-term storage on Mald 1content of four apple cultivars with initial low Mal d 1content. Journal of Science of Food and Agriculture, 94, 798-802. http://dx.doi.org/10.1002/jsfa.6448

KOOTSTRA, H.S., VLIEG-BOERSTRA, B.J., DUBOIS, A.E. 2007 Assessment of the reduced properties of the Santana apple. Annals of Allergy, Asthma \& Immunology, 99,522-525. http://dx.doi.org/10.1016/S1081 1206(10)60381-X

KOPLIN, J. J., PETERS, R. L., PONSONBY, A.L., GURRIN, L.C., HILL, D. TANG, M.L., DHARMAGE, S.C., ALLEN, K.J. 2014. Increased risk of peanut allergy in infants of Asian - born parents compared to those of Australian - born parents. Allergy, 69(12), 1639-1647. http://dx.doi.org/10.1111/all.12487

LOMBARDERO, M., GARCÍA-SELLÉS, F.J., POLO, F., JIMENO, L., CHAMORRO, M.J., GARCÍA-CASADO, G., SÁNCHEZ-MONGE, R., DÍAZPERALES, A., SALCEDO, G., BARBER, D. 2004. Prevalence of sensitization to Artemisia allergens Art v 1, Art v 3 and Art v 60 kDa. Cross-reactivity among Art v 3 and other relevant lipid-transfer protein allergens. Clinical and Experimental Allergy, 34(9), 1415-1421. http://dx.doi.org/10.1111/j.1365 2222.2004.02053.x

MARI, A., ALESSANDRI, C., BERNARDI, M. L., FERRARA, R., SCALA, E., ZENNARO, D . 2010. Microarrayed allergen molecules for the diagnosis of allergic diseases. Current Allergy and Asthma Reports, 10, 357-364. http://dx.doi.org/10.1007/s11882-010-0132-0

MOTHES-LUKSCH， N., RAITH， M. STINGL，G., FOCKE-TEJKL, M., RAZZAZI-FAZELI, E., ZIEGLMAYER, R., WÖHRL, S., SWOBODA, I. 2017. Pru p 3, a marker allergen for lipid transfer protein sensitization also in Central Europe. Allergy, 72: 1415 - 1418. http://dx.doi.org/10.1111/all.13151

NWARU, B.I., HICKSTEIN, L., PANESAR, S.S., MURARO, A., WERFEL, T. CARDONA, V., DUBOIS, A.E. HALKEN, S., HOFFMANNSOMMERGRUBER, K., POULSEN, L.K., ROBERTS, G., VAN REE, R. VLIEG-BOERSTRA, B.J., SHEIKH, A. 2014. The epidemiology of food allergy in Europe: a systematic review and meta-analysis. Allergy, 69, 62-75 http://dx.doi.org/10.1111/all.12423

PASTORELLO, E.A., PRAVETTONI, V., FARIOLI, L., RIVOLTA, F., CONTI, A., ISPANO, M., FORTUNATO, D., BENGTSSON, A., BIANCHI, M. 2002. Hypersensitivity to mugwort (Artemisia vulgaris) in patients with peach allergy is due to a common lipid transfer protein allergen and is often without clinical expression. Journal of Allergy and Clinical Immunology, 110(2), 310-317.

PONCET, P. SENECHAL, H., CLEMENT, G., PUROHIT, A., SUTRA, J.P., DESVAUX, F.X., WAL, J.M., PAUli, G., PELTRE, G., GOUGEON, M.L. 2010. Evaluation of ash pollen sensitization pattern using proteomic approach with individual sera from allergic patiens. Allergy, 65, 571-580. http://dx.doi.org/10.1111/j.1398-9995.2009.02231.x

REVAK, O., GOLIAN, J. 2012. Nutrition labelling of food and allergen in food. Potravinárstvo,. 6 (3), p. 28-31. http://dx.doi.org/10.5219/230

SANCHEZ-MONGE, R. BLANCO, C., LOPEZ-TORREJON, G., CUMPLIDO, J., RECAS, M., FIGUEROA, J., CARRILlO, T., SALCEDO, G. 2006 Differential allergen sensitization patterns in chestnut allergy with or without 
associated latex-fruit syndrome. Journal of Allergy and Clinical Immunology, 118(3), 705-710.

SHAHALI, Y., NICAISE, P., BRÁZDOVÁ, A., CHARPIN, D., SCALA, E., MARI., A., SUTRA, J.P., CHOLLET-MARTIN, S., SÉNÉCHAL, H., PONCET, P. 2014. Complementarity between microarray and immunoblot for the comparative evaluation of $\mathrm{IgE}$ repertoire of French and Italian cypress pollne allergic patients. Folia Biologica (Praha), 60, 192-201.

SCHÄPPI, G.F. KONRAD, V., IMHOF, D., ETTER, R., WÜTHRICH, B. 2001. Hidden peanut allergens detected in various foods: findings and legal measures. Allergy, 56:1216-1220.

SMOLE, U., BUBLIN, M., RADAUER, C., EBNER, C., BREITENEDER, $\mathrm{H}$ 2008. Mal d 2, the thaumatin-like allergen from apple, is highly resistant to gastrointestinal digestion and thermal processing. International Archives Allergy Immunology, 147(4), 289-298. http://dx.doi.org/10.1159/000144036

URL 1 - http://www.meduniwien.ac.at

VLIEG-BOERSTRA, B.J. VAN DE WEG, W.E., VAN DER HEIDE, S., KERKHOF, M., ARENS, P., HEIJERMAN-PEPPELMAN, G., DUBOIS, A.E. 2011. Identification of low allergenic apple cultivars using skin prick tests and oral food challenges. Allergy, 66, 491-498. http://dx.doi.org/10.1111/j.13989995.2010.02499.x

VLIEG-BOERSTRA, B.J., VAN DE WEG, W.E., VAN DER HEIDE, S. SKYPALA, I., BURES, P., BALLMER-WEBER, B.K., HOFFMANNSOMMERGRUBER, K., ZAULI, D., RICCI, G., DUBOIS, A.E. 2013 Additional indications for the low allergenic properties of the apple cultivars Santana and Elise. Plant Foods for Human Nutrition, 68, 391- 395. http://dx.doi.org/10.1007/s11130-013-0385-6

WAGNER, A. SZWED, A., BUCZYŁKO, K., WAGNER, W. 2016. Allergy to the apple cultivars among patients with birch pollinosis and oral allergy syndrome. Annals of Allergy and Asthma Immunology, 117(4), 399-404 http://dx.doi.org/10.1016/j.anai.2016.08.015

WANGORSCH, A., SCHÜLKE, S., GADERMAIER, G., ALBRECHT, M., WALLNER, M., RANDOW, S., WOLFHEIMER, S., LIDHOLM, J., LAUER, I., FERREIRA, F., TODA, M., VIETHS, S., REESE, G., SCHEURER, S. 2014 LTP cross-reactivity - primary sensitization to mugwort pollen LTP Art v 3, facilitates subsequent sensitisation to peach LTP Pru p 3 in mice. Clinical and Translational Allergy, 4,O14. http://dx.doi.org/10.1186/2045-7022-4-S2-O14 WORM, M., WORM, M., REESE, I., BALLMER-WEBER, B., BEYER, K., BISCHOFF, S.C., CLASSEN, M., FISCHER, P.J., FUCHS, T., HUTTEGGER, I., JAPPE, U., KLIMEK, L., KOLETZKO, B., LANGE, L., LEPP, U., MAHLER, V., NIGGEMANN, B., RABE, U., RAITHEL, M., SALOGA, J. SCHÄFER, C., SCHNADT, S., SCHREIBER, J., SZÉPFALUSI, Z., TREUDLER, R., WAGENMANN, M., WATZL, B., WERFEL, T., ZUBERBIER, T., KLEINE-TEBBE, J. 2015. Guidelines on the management of IgE-mediated food allergies: S2k-Guidelines of the German Society for Allergology and Clinical Immunology (DGAKI) in collaboration with the German Medical Association of Allergologists (AeDA), the German Professional Association of Pediatricians (BVKJ), the German Allergy and Asthma Association (DAAB), German Dermatological Society (DDG), the German Society for Nutrition (DGE), the German Society for Gastroenterology, Digestive and Metabolic Diseases (DGVS), the German Society for Oto-RhinoLaryngology, Head and Neck Surgery, the German Society for Pediatric and Adolescent Medicine (DGKJ), the German Society for Pediatric Allergology and Environmental Medicine (GPA), the German Society for Pneumology (DGP), the German Society for Pediatric Gastroenterology and Nutrition (GPGE), German Contact Allergy Group (DKG), the Austrian Society for Allergology and Immunology (Æ-GAI), German Professional Association of Nutritional Sciences (VDOE) and the Association of the Scientific Medical Societies Germany (AWMF). Allergo Journal International, 24:256-293. http://dx.doi.org/10.1007/s40629-015-0074-0

YAMAMOTO, T., KUKUMINATO, Y., NUI, I., TAKADA, R., HIRAO, M., KAMIMURA, M., SAITOU, H., ASAKURA, K., KATAURA, A. 1995 Relationship between birch pollen allergy and oral and pharyngeal hypersensitivity to fruit. Nippon Jibiinkoka Gakkai Kaiho, 98(7):1086-1091. ŽIAROVSKÁ, J., ZELENÁKOVÁ, L. 2017. Disproporcionalita poznatkov a praxe - zaostáva značenie rastlinných alergénov?: Disproportionality of knowledge and practice - does the labeling of plant allergens lag?. XLVII. Lenfeldovy a Höklovy dny. Brno: Veterinární a farmaceutická univerzita., pp. 266-273. ISBN 978-80-7305-793-0.

ŻIAROVSKÁ, J., ZELEŇÁKOVÁ, L. 2019. Application of Genomic Data for PCR Screening of Bet v 1 Conserved Sequence in Clinically Relevant Plant Species. In: Vlachakis, D. (ed). Systems Biology, IntechOpen, ISBN: 978-183880-804-4. http://dx.doi.org/10.5772/intechopen.80312 